\title{
The Great Wall as Perilous Frontier for the Mongols in 16th Century: Reconsidering Nomadic-Sedentary Relations in Premodern Inner Asia *
}

Temur Temule**

\section{Introduction}

In his paper "Beiya youmu minzu nanqin gezhong yuanyin jiantao" (An examination of various factors for Northern Asian nomads' southward invasion), which was published in 1972, Xiao Qiqing argued, "The challenge to agricultural peoples by nomadic peoples, and the response of those agricultural peoples, is one of the most important issues in premodern world history. Since the invention of equitation, the nomads of

* In writing this paper, the author gave talks related to this topic and received valuable comments and encouragement. Talks include the 11th Institute of Central Eurasian Studies Seminar (October 2009) organized by Prof. Kim Hodong of Seoul National University; the Annual Meeting of Mongolian History in China (July 2012) ; Osaka Toyoshi Kenkyushitsu (January, 2013) ; and a talk at the History Department of Pennsylvania State University (March 2013). In early 2013, the author visited Tokushima University and finally got a chance to read relevant parts of Mindai Mōko shi kenkyū by Hagiwara Junpei. Professor Aratake Tatsuroof Tokushima University helped with the Chinese translation of Japanese sources. Professor Hei Long read through the whole paper and provided valuable comments. I would like to thank all of them here.

** Associate Professor, College of History, Nanjing University 
the Eurasian steppe - from the Xing'an Ridge to Hungary - relied on their superiority in equitation and archery, and became the biggest threat to neighboring farmers. Only when the Manchu Qing dynasty and Russia started expanding into Inner Asia in the seventeenth century were the nomads vanquished, with the help of rifles and cannons. ${ }^{1}$ The relationship between nomads and farmers is one of the most important topics in Inner Asian and East Asian history, and world history as well. It has long attracted attention from scholars all over the world. Recently, along with the publication of Wang Mingke's book Youmuzhe de Jueze: Miandui Han Diguo de Beiya youmu buzu (The Choice of Nomads: Xiongnu that Faced the Han Empire), the Chinese translation of Ancient China and its Enemies: The Rise of Nomadic Power in East Asian History by Nicola Di Cosmo, and the publication in China of the Perilous Frontier: Nomadic Empires and China 221 B.C. to AD 1757 by Thomas Barfield, have again drawn large-scale attention from scholars to nomadic-sedentary relations. Scholars in this field have again started to ponder the question raised by Wang Xiaofu: "Why did the ancient nomads choose to invade agricultural areas? What were the decisive factors that determined relations between these two groups of people?"2

Regarding the reasons for nomads invading the South, Xiao Qiqing did a "systematic evaluation of arguments presented by Chinese and foreign scholars" and concluded that there were seven types of major arguments: "[nomads'] inborn greed to plunder; climate change; population density; trade; modes of production; the need by nomadic chiefs to reinforce their

1 Xiao Qiqing, "Beiya youmu minzu nanqin gezhong yuanyin jiantao," Shihuo yuekan 1:12; Yuandaishi xintan (Xinwenfeng chubangongsi, 1983), 303-322. Xiao used the term "premodern world history," and the subtitle of this paper also uses the term premodern. Inner Asia refers to the inner lands of Asia, with the author believing that Sino-Mongol interactive areas in the sixteenth century-along the Great Wall — represent the southeastern edge of Inner Asia.

2 Wang Xiaofu, "Lun gudai youmu buzu ruqin nonggeng diqu wenti," in ed. Wang Xiao Fu, Tang Tubo Dashi Zhengzhi guanxishi (Beijing: Beijing daxue chubanshe, 1992), 289-292. 
power; and desire for equilibrium between South and North.", At the end of his paper, Xiao contended, "The southward invasion of the nomads was deeply rooted in their economic system. The nomadic economy is vulnerable to natural changes, and hence needs to rely upon agricultural society. Moreover, nomads were always slow in adopting manufacturing skills. Trade and raid against an agricultural society were two resolutions for the nomadic economy." In 1988, Wang Xiaofu also argued that "relations between nomadic and agricultural societies were in fact the basis for the continuity and extension of internal affairs in the north, and South-North relations were in fact an extension of internal affairs in the north." Most scholars have attempted to find a rationale for raiding by looking at conditions within the nomadic society. Wang was keen to claim that "most scholars gave emphasis to the nomadic society," but at the same time Wang conceded that there is a valid reason for that belief. Now the question is, is it still a valid approach to emphasize factors related to the nomadic society?

As Reuven Amitai and Michal Brian argued in the preface of the book they edited, Mongols, Turks, and Others: Eurasian Nomads and the Sedentary World, “...The reality of nomadic-sedentary relations is

3 Among them, the majority of scholars leaned toward the hypothesis of the blocking trade formula. What is trade or raid? According to Jaqchid Sechin, "if there is trade there is peace; no trade, then war." (Zhaqisiqin, Beiya youmuminzu yu zhongyuan nongye minzu jiande heping zhanzheng yu maoyi guanxi (Taibei: Zhengzhong shuju, 1973), 14.

Henry Serruys pointed out that "in most cases there were not wars but raids." See preface, Serruys, Sino-Mongol relations during the Ming III : Trade Relations, the Horse Fairs : 1400-1600 (Bruxelles : Institut belge des hautes études chinoises, 1975).Therefore, a trade or raid formula can be interchangeable with the idea that if "There is trade then peace; no trade, then raid." Scholars summarized this as the "trade or raid formula," which is the equivalent of the blocking trade hypothesis.

4 Wang Xiaofu, "Lun Gudai youmu buzu ruqin nonggeng diqu wenti," in Wang Xiao Fu, Tang Tubo Dashi Zhengzhi guanxishi (Beijing: Beijing daxue chubanshe, 1992), 289-292. 
apparently more varied than some of the models have led us to think...", This is an insightful perception. Now, how do we approach "the reality of nomadic-sedentary relations?" How do we deepen and enrich our knowledge through exploring this question? It should be noted that the two hundred years of Ming-Mongol relations represents the last round of nomadic-sedentary confrontation. The interaction of the Ming and Mongols along the Great Wall before the Manchus' rise in the sixteenth century was frequently referred to in historical documents, through which we perhaps can find a more accurate answer to that question.

\section{0: The Daičing Ejei Taiji Incident and its Consequences}

On October 16, 1570, the grandson of the Southern Mongolian Tümed chief Altan Khan, Daičing Ejei Taiji, accompanied by his wife, retainers, and a dozen bodyguards, fled to the Ming border through Pinglu Fortress of the military district of Datong and surrendered to the Ming dynasty. Xuanda Governor-General Wang Chonggu and Datong Magistrate Fang Fengshi gathered information by interrogating Taiji:

"Daičing Ejei Taiji was the son of the third son of Altan Khan. His father, Tiebeitaiji, died when he was only four, and he was raised by his grandmother Yikehatun, who also arranged a marriage for him with the daughter of a Fanshen chief. The name of the bride-to-be was Biji....Not long before the marriage, Altan Khan took a girl who was engaged to the Ordos chief, which enraged the Ordos chief, and Altan Khan gave him Taiji's fiancée to appease the Ordos chief. Taiji was furious (about losing his fiancée), and hence he departed from his grandfather and grandmother, and went to the South." 6 This incident was summarized in this way:

5 Reuven Amitai and Michal Brian, "Introduction" in Mongols, Turks, and Others: Eurasian Nomads and the Sedentary World, eds. Reuven Amitai \& Michal Biran (Leiden \& Boston: Brill, 2005), 11.

6 "Bingbu zoushu" 1-2, in Zhongguo wenxian whengben congshu (Quanguo 
"There was internal strife among family members, and a rebellion occurred from inside." After Wang Chonggu and Fang Fengshi found out the reason for Taiji's surrender, they decided to take him hostage and started negotiations with Altan Khan. ${ }^{7}$

It was such a shocking incident that Ming-Mongol relations fell into a state of crisis. Altan Khan retreated from his westward expedition and returned to Southern Mongolia. He dispatched numerous cavalrymen to patrol around Pinglu Fortress, hoping to force the Ming dynasty to return his beloved grandson. Wang Chonggu also sent his special envoy Bao Chongde to Altan Khan's camp, and promised that he would send Taiji back if Altan Khan would expatriate some Chinese rebel leaders. Bao Chongde came back with five envoys of Altan Khan to the military district of Datong, and they met with Wang Chonggu. ${ }^{8}$ Thus the hostility

tushuguan wenxian suowei fuzhi zhongxi ju guojia tushugauncan chaoben yingyin, 2007). Here Fanshen was a typo of Wushen(üüšin). Grandma Yikehatun should be Altan Khan's first wife Yeke qatun. Bahannaji is usually believed to be the Chinese transcription of little grandson. According to the Mongolian document Erdeni Tunumal neretü Sodor Orošiba, his name was recorded as Daičing Eǰei Taiji, which corresponded with "Dacheng aiji taiji" in the biography of Bahanaji in Wanli Wugonglu. Therefore, Bahannaji is more likely to be a transcription of ba'aqan-ejei. See Erdeni Tunumal neretü Sodor Orošiba, Köke-qota: Altan Qayan

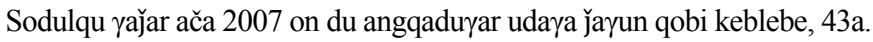

7 Dictionary of Ming Biography 1368-1644, ed. Carrington Goodrich \& Chaoying Fang (New York\& London: Columbia University Press, 1976), 1371. It is said that Wang Chonggu at first kept this incident secret before he reported it to the Beijing. The author believed that Zhang Juzheng should have known about this before Wang's report. Zhang wrote to Wang, "Someone who came from Yunzhong told me that there was a grandson of the Mongol chief there who came to surrender. There is only one son of Altan Khan that is alive, Huangtaiji. Is that grandson the son of Huangtaiji? Why did he come to surrender? Why didn't you report about this? If it is true, this is a critical incident for border affairs. Please handle with caution, and confirm what I heard." See Zhang Taiyue ji (Shanghai guji chubanshe 1984), 265. It is obvious that Zhang had obtained information from another source.

8 Regarding Ming-Mongol negotiation in this period, see Temur Temule, "Mingmeng jiaoshezhong de menggu shichen daerhanshoulingge." Minzu yanjiu 2 
and suspicion of each other that had accumulated over years started to ease, and the Mongol chief also came to realize the importance of the Bansheng Chinese rebels to the Ming dynasty, as well as the feasibility of reconciliation. On December 16, 1570, the envoy of Altan Khan took Zhao Quan (the leader of the Chinese White Lotus Rebellion) to Left Commandery of Datong Fortress. On the second morning, the Ming troops escorted Taiji to the Sino-Mongol border. In the middle of negotiations, Altan Khan proposed arrangements for tribute and trade. Propelled by Wang Chonggu and Fang Fengshi, and supported by Gao Gong and Zhang Juzheng from the Ming court, the Sino-Mongol contingent reached a peace agreement in April 1571; the agreement is called "Longqing Fenggong (Sino-Mongol Treaty of 1571)." This heralded a new era of Sino-Mongol relations along the west border of the Great Wall.

In retrospect, the thirty years before 1571 was a period of "repeated war and hostility." The temporary discord between the grandfather and grandson made the grandson surrender to the Ming, and this accidental crisis laid the foundation for the consequent reconciliation. How could this happen? As Cao Yongnian contended:

In the beginning of the Longqing reign, Altan Khan often invaded Ming territory, relying upon his military superiority. Under this circumstance, the Daičing Ejei Taiji Incident suddenly turned war into peace, and the peace continued till the end of the Ming dynasty without any major change. This is a thought-provoking process. Though it can be said that Chinese ministers and governors had made a wise decision, however, the real initiative was with Altan Khan. ${ }^{9}$

Cao concluded that several natural disasters in a row and a dispute (2011).

9 Cao Yongnian, Menggu minzu tongshi, vol. 3 (Neimenggu daxue chubanshe, 1991), 303. 
between the Mongol elites and Chinese rebels actually pushed Altan Khan to opt for a peace negotiation. However, another prominent historian, Dalizhabu Bao, disagreed. He pointed out that Cao Yongnian overstated the importance of the Chinese rebels, and that "Altan Khan's expatriation of the Chinese rebels did not mean that they could not get along. The Chinese who turned themselves in to the Mongols became subject of Mongol aristocrats, and their lives were at the disposal of the Mongol elites. The Chinese rebels who were traded over can well represent their status from the Mongols' perspective." Regarding this initiative, Dalizhabu Bao stated:

The internal problem among the Mongol elites was not the primary reason for 'Longqing Fenggong'. The resumption of trade was decided by the Ming dynasty regardless of Altan Khan. Trade had always been the goal that Altan Khan tried to achieve using all possible means, but his efforts were in vain. Therefore internal strife among Mongols or Altan Khan's changing attitude is not the reason for the peace negotiation. ${ }^{10}$

Dalizhabu Bao instead argued that Ming Emperor Shizong had insisted on an isolation policy that left the Mongols with no choice but to raid. The Ming dynasty had spent too much on border defence and exhausted their financial resources; hence this is the primary reason the Ming changed their policy.

It is obvious that there is a gap between the views of Cao Yongnian and Dalizhabu Bao. However, they still have one point in common: regardless of who initiated the "Longqing Fenggong," they both agree that the Ming and Mongols had been searching for ways to move toward reconciliation. Now let us ask a question from the opposite perspective: in the process of preparing to move toward the "Longqing Fenggong," what kind of factors obstructed the Fenggong? Asking the question in this way may help trace

10 Dalizhabu Bao, Mingdai monan menggu lishi yanjiu (Neimenggu wenhua chubanshe, 1998), 225. 
the historical reality of the decades before 1570, and deepen and enrich our knowledge of the interactive history of premodern nomadic-sedentary relations.

\section{Prohibition on Daochao (搗巢) and Opposition from the Ming Generals}

In dealing with the Daičing Ejei Taiji Incident, Altan Khan proposed a tribute and trade agreement on behalf of the Mongol Tümed tribe. They of course hoped to reach Fenggong. The Ordos tribe based in the Hetao area also quickly joined the negotiation proactively. The Qarachin tribe, which resided in the Jinlian Steppe area outside of Xuanfu, initially were not enthusiastic, but later were convinced by Altan Khan and Ming envoys; they also joined the Fenggong peace talk. In contrast to the Mongolian aristocrats, the Bansheng Chinese were the last ones who wanted to see a Sino-Mongol reconciliation, but their leaders were handed over to the Ming government, and hence they could not really impede the peace talks. Thus was the situation on the Mongol side. On the Ming side, the Xuanfu governor-general Wang Chonggu and Fang Fengshi were very enthusiastic to reach the Fenggong, and their approaches were supported by Gao Gong and Zhang Juzheng. The magistrates of Shaanxi sanbian initially opposed the idea but later came around. Some ministers of the Beijing central government also opposed reconciliation with Mongols, but "the power was mainly controlled by Gao Gong, Zhang Juzheng, Wang Chonggu, and Fang Fengshi, who handled the opposition effectively," hence the oppositional camp could not create any major obstacles for the peace talks. However, there is one more group that was important but often neglected in historical analysis: when Wang Chonggu and Fang Fengshi planned fenggong, the generals at the military districts of Xuanfu and Datong rose to oppose it, and the leaders among them were Ma Fang and Zhao Ke. Why did they oppose the fenggong between the Ming and the Mongols? 
In late November 1570, the Ming and Mongols exchanged hostages. In the following months, Wang Chonggu and Fang Fengshi worked hard to reach the fenggong agreement. Wang and Fang also hoped that Altan Khan would ally with the Qarachin, Yongshiyebu, and Ordos tribes to sign the fenggong agreement with the Ming dynasty. In the meantime, Wang Chonggu ordered a ban on daochao. Regarding this prohibition, according to Wanli Wugong lu (The Record of Military Affairs during the Wanli Reign), its purpose was "to reduce the activities of burning the grassland, daochao and ganma 赶馬, so that it can show the Ming's sincerity toward the Mongols." 11 The prohibition and forthcoming peace agreement aroused severe opposition from the Ming generals, and their responses are recorded in historical documents. We can see that Ming generals opposed the peace talks and fenggong relations, and they once even challenged Governor-general Wang Chonggu. In regard to this, the recent reprint of Bingbu zoushu (Memorials of the Ministry of War) has one particular entry that requires special attention. In the first month of 1571, Wang Chonggu dispatched his envoys Li Ning and Yang Liang to visit the Mongol Yongshiyebu and Qarachin tribes. They were accompanied by an assistant of Altan Khan, and their aim was to convince those two tribes to join the fenggong talks. On the thirteenth of the first month, the Ming envoy visited the Qarachin camp and told the chief, "The Ming generals opposed fenggong because they were afraid that fenggong would block them from making money out of daochao and ganma. They tried to ally with each other, which infuriated our grand master, and the grand master punished a couple of them. Our grand master thus commanded that Ming troops should only focus on defense and can only chase the offending Mongols, and cannot go out of the fortress without obvious reason." 12 The term grand master here referred to

11 "Zhong sanbian Antan liezhuan xia" in Wanli Wugonglu(Zhonghua shuju yingyinben, 1962), vol. 8. Zhongsanbian Anda leizhuan, $14 \mathrm{~b}$.

12 "Bingbu zoushu" in Zhongguo wenxian zhenben congshu (Quanguo tushuguan suowei fuzhi zhongxin, 2007), 281-82. 
Wang Chonggu, and the Ming generals he punished include Ma Fang and Zhao Ke. In the process of persecution, Wang continued his communication with Zhang Juzheng, and Zhang Juzheng stated, "Ma and Zhao have been defense generals for a long time. Zhao is hard but still loyal to the government, hence he can still be tamed. Ma has been cunning and often conspired with raiders. Some of Ma's subjects were real Mongols, and $\mathrm{Ma}$ was the last one to hear about fenggong. He deserved to be punished. However, it is hard to kill him, so please find the proper way to ensure that he won't rebel." "13 According to Zhang, Zhao was tough but wouldn't cause real trouble. It was Ma who hated to see the fenggong and openly opposed it, and eventually Zhang had to step in to mediate between Wang and Ma. The opposition among generals diminished after the punishment.

Shaanxi Sanbian was not under the jurisdiction of Wang Chonggu; hence Wang could not enforce the termination of daochao against the Ordos Mongols. Wang could only make a proposal to the central government to ban daochao, "I would like to sign an agreement with Altan Khan and have him vow not to invade us. Please ban daochao so that we can affirm the power of our sacred dynasty, appease the barbarians, eliminate the reason for raids, and solve the border problem once and for all." ${ }^{14}$ However, right before the prohibition edict reached this area, the Mongol Ordos aristocrats took revenge against the Yulin retainer for stealing their horses, and this led to a new round of border conflicts, which was named "The Incident of Shuangshanbao." According to the biography of Ji'neng in Wanli wugonglu, "At the time, the Ming

13 Zhang Taiyue ji, 272. Zhang Juzheng said that there were many real Mongols under Ma Fang, and that he always contrived with Mongols. It is thoughtprovoking. The conspiracy means that Ma had connections with chiefs in Southern Mongolia, particularly Tümed chiefs. When Bao Chongde visited Altan Khan, he requested that Altan Khan only keep a couple of very trustworthy fellows around for the meeting. According to Erdeni Tunumal neretü Sodur, all this confirmed that Ma Fang secured his source of intelligence in Southern Mongolia.

14 Ming jingshi wenbian, 316: 3354-3356. 
generals all claimed credit for daochao and ganma, which led to the Incident of Shuangshanbao. Wang Chonggu worried that this could be an excuse for a Mongol invasion. Wang forbade daochao and ganma, and announced the death penalty for Ming generals who violated it." ${ }^{15}$ Once the prohibition edict arrived, there was no more military conflict in the Shaanxi area.

What is daochao? The CICM missionary Henry Serruys explained that the terms daochao and ganma "occur regularly as an expression to describe Chinese forays into Mongolia, usually with the purpose of stealing horses; this was considered the best tactic to forestall Mongol raids." 16 Serruys' explanation made some sense but didn't explain everything. As Yang Bo (the Minister of War of the Ming dynasty) explained in his memorial to the Ming emperor in February 1561, "Normally there are two ways of daochao: the first is to strike the Mongols' home base when the enemy invades so that they have to retreat and focus on their internal issues; the other one is to send troops out to attack their home base when they are not ready. The Ming defense army has utilized these strategies very often lately. Recent examples are the Victory of Datong and Fengzhou. However, if they didn't plan well and instead struck out in a rush, then they could wind up doing more harm than good. The border officials all follow Li Wenjing's advice when they attack Mongols, and only strike when a full victory is possible, which can be considered the superior strategy." "The first point Yang mentioned fits with Henry Serruys's explanation-that Daochao meant attacking Mongols' a'uraq (home base) while they were out invading so that the

15 Qu Jiusi, "Xisanbian Jineng leizhuang," in Wanli wugonglu (Zhonghua shuju yingyinben, 1962)14: $1 \mathrm{~b}$.

16 Henry Serruys, Sino-Mongol Relations during the Ming II, the Tribute System and Diplomatic Missions II (Bruxelles : Institut belge des hautes études chinoises, 1967),76.

17 Yang Bo "Fuxuanda zongdu duyushi Li Wenjin tiaochen bianji shu", in Yangxiangyigong zoushu Benbing zoushu, vol. 3, (Beijing tushuguan guji zhenben songcan) 110, 473. 
Mongols' further advancement could be contained. However, the action of daochao was not only for defense, but also could be used for offense, as was the case when the Ming army went out hundreds of $l i$ to attack the Mongols at a time other than harvest season on the steppe. This is what $\mathrm{Qu}$ Jiusi had in mind when he said, "Some generals took credit for daochao and ganma." These risky moves were tolerated or even encouraged by the Ming court.

Who were the people who organized and participated in daochao and ganma? The "Jiangshuai Jiading" entry in Nianershi zhaji or the Commentary of Twenty-Two Historical Records, written by Zhao Yi, stated,

When two troops are at war, all depends on a brave general. If the general is brave then soldiers will follow. However the general also needs his assistants and collaborators, so that all can be brave and move forward. The general advances, and soldiers also fight hard; so it is important for a general to have his retainers. There were previous successes for Hanyue's army, and the Mingshi recorded that sixteen of Yang Hong's retainers got promoted to the ranks of officials. Wang Yue also secured numerous brave soldiers and fought with his enemies, earning fame out of this. During the year of Jiajing, Japanese pirates came from across the sea, and the Ming summoned the old generals He Qing and Shen Xiyi to lead their retainers to fight the pirates. Ma Yong was a general, and he had over one hundred retainers who were all brave northwestern strongmen and were good at war. The Ming emperor once asked Li Shi for a good general, and Li Shi recommended Ma Yong, and particularly suggested that 'Ma's retainers can be of good use.' Ma Fang recruited retainers, and he once dispatched his retainers over four hundred $l i$ to kill and capture many enemy soldiers. Liang Zhen also has five hundred retainers defending Datong. At some time the Datong soldiers got arrogant and killed their governors and other soldiers, but they were scared and astonished when Liang Zhen came with his retainers. When Liang died, his retainers merged to form troops and Liang's successor got the benefit of it. In the year of Wanli, Li Chengliang 
took control of Liaodong and recruited brave men, paid them well and used them as vanguards, which was very successful. Among them, Li Pinghu and Li Ning were later promoted to generals. ${ }^{18}$

Generals and their retainers formed multiple groups for daochao and ganma. Ma Fang and Zhao Ke were the leaders of these kinds of groups. According to data from 1571, Ma Fang had 696 retainers, and Zhao Ke had 1,241. These retainers were the "brave warriors" mentioned by Zhao $\mathrm{Yi}$, or in other words, they were private mercenaries. There were many Mongols among them, and among Ma Fang's men in particular, because Ma often "conspired with the Mongols, and many retainers of Ma were real Mongols."

Why did they take the risk to commit daochao? Their primary reason was ganma, or stealing horses. During the decades before the "Longqing Fenggong," daochao and ganma had already become a source of revenue, or an interest chain, due to the hostility between the Ming and Mongols. ${ }^{19}$ A Ming-Mongol peace would block the obtaining of financial resources through daochao and ganma, so they stepped out and opposed the fenggong. They also had their supporters in the central government. Wang Chonggu criticized these generals who became arrogant because of their past fame, and stated:

Now some generals may be brave but ignorant of military strategy, calculating while betraying. In peace time they recruit retainers and seek a chance to conduct daochao and ganma for claiming credit and securing

18 Nianershi zhaji jiaozheng (Zhonghua shuju, 1984), 34: 777-778.

19 Here we find a very interesting contrast. Barfield considered the Xiongnu the frontier parasites of the Han dynasty, and trade and raid against the Han was the Xiongnu's stream of wealth. However during the Ming-Mongol confrontation period, it was the Ming generals' retainers who considered daochao and gamna to be a financial venue. The purpose is similar, though the reality (aggressor-victim) is opposite. See Thomas Barfield, Perilous Frontier: Nomadic Empires and China (Cambridge Mass.: Blackwell, 1989), 91. 
money. But in the face of danger they are hesitant and just try to avoid death. Now the Mongol chief begs for tribute, and these generals are not cooperative. If it were really like what they argued, that there were multiple raids by the Mongols lately, why can they not have one face-to-face decent fight and make a name for themselves on their strength? They are always hesitant and wander around, and everybody knows it. They occasionally go out for daochao but only kill the old, the young, and women, and never attack the main Mongol troops. They did ganma but only got old and useless mules and ponies: this is more like bullying. Why did the state support these generals who can achieve nothing but making a disaster on the battlefield ${ }^{20}$

Wang Chonggu was critical of them because Ma Fang rarely attacked invading Mongol troops. When there was a war, they simply "wandered around and avoided fighting; they just wanted to escape death." However during peacetime, they "recruited soldiers and sought chances for daochao and ganma in order to secure their private interests." They opposed fenggong just to protect their private interests, while in fact they never had the courage to fight against the invading Mongols and defend their borders. This could only bring revenge from the Mongols, and so was not helpful at all for border security. This was their normal course of action in the Xuanda and Shanxi areas along the Great Wall front. In this sense, the Great Wall fortress was nothing more than their asylum, and their primary goal for daochao was stealing horses and claiming false credit.

In March of the Longqing $5^{\text {th }}$ year, the fenggong proceeded smoothly. However, how were those retainers who committed daochao and ganma to be disposed of? This was a serious issue from the Ming perspective. Before, the Ming court had tolerated and encouraged daochao and ganma, but now the government suddenly changed the policy to prohibition; how could the government defend their change of policy? How to appease

20 Ming jingshi wenbian (Zhonghua shuju, 1964), 4: 3368. 
Ming generals such as Ma Fang became an important issue for the Ming government. The Minister of War, Yang Bo, said, "Ma Fang, Zhao Ke, and $\mathrm{Guo} \mathrm{Hu}$ are all capable generals. Though they initially opposed fenggong, trade succeeded eventually, and those generals were not sufficiently rewarded for their credit." ${ }^{21} \mathrm{He}$ addressed this issue very implicitly. Ma Fang was punished because of his initial opposition to fenggong, while fenggong succeeded anyway. The court needed to convince everyone, and to rectify their previous tolerance and encouragement of daochao and ganma. According to Wang Shizhen, the Ming government eventually decided to promote Ma Fang, Zhao Ke, and Ma Jingshi to senior official ranks. ${ }^{22}$ Promotion and reward seemed to be sufficient to appease their resentment. But how to deal with their retainers? After the Fenggong, Ma and Zhao dismissed their retainers, but they knew that if they lost their means of living, they could threaten the local society. In December of the fifth year of Longqing, Yang Bo replied to Wang Chonggu, noting, "The fortress was undefended, subjects rebelled, warriors scattered, and the number of (illegal) markets increased beyond control." He went on to explain, "Border soldiers gradually became lazy. The Ming generals recruited too many retainers. At Xuanda, Ma Fang has 696, and Zhao Ke has 1,241. In the past they did daochao and ganma, making profits for personal gain. Now they have neither external funds nor self-reliance, and are gradually growing grumpy and are running away. However most of them were surrendered barbarians and are not good at farming; besides, there is no extra land to distribute to them. Now merge all retainers with rank one and rank two, provide them a stipend and food, and support their families." ${ }^{23}$ It is noteworthy that retainers under Ma Fang were mostly barbarians, and mostly non-farming Mongols. ${ }^{24}$ The Ming government felt the need to make a policy to

21 Yanxiangyigong benbing shuyu, chapter 22, in Xuxiu Sikuquanshu477: 632.

22 Wang Shizhen, "Shima kao," in Yanshangtang bieji (Zhonghua shuju, 2006)89: 1716.

23 Yangxiangyigong benbing shuyi, chapter 23. Xuxiu Sikuquanshu477: 655. 
provide them with a stipend. Before the "Longqing Fenggong," the Ming government didn't provide any stipend to retainers, and retainers relied upon daochao and ganma for provision, while Ming generals also resorted to daochao and ganma to raise money for their retainers while at the same time glorifying themselves. Once the "Longqing Fenggong" was finalized, it was forbidden to go out for daochao and ganma, and the retainers' standard of living deteriorated. It fell to the Ming government to provide stipends, and the retainers' families received funding. As a result, the Ming government incurred a tremendous expense not only for rewarding the Mongol aristocrats, but also for providing stipends for the Ming generals' retainers.

\section{Ming-Mongol Relations, between 1540-1570}

What was the role of daochao and ganma during the decades before 1570? Among the military districts along the Great Wall, Jizhou was special in that its residents did not go out for daochao and ganma. Zhang Juzheng stated, "Jizhou is different from other military districts, and its strategy for defense and offense is also different. This area was initially not a border area, but rather is close to the Ming royal cemetery. Therefore while other fortresses need to fight in order to defend, as for this place, defense is truly just defense. For other fortresses you need to kill the enemy for credit, but here the key is not to let the enemy break in. It is because of its special geography. ${ }^{, 25}$ In 1594, Jiliao Governor Sun Kuang said, "The tradition in Jimen is that its superior defense does not

24 Wubian dianze, chapter 10. "Each section of the border recruited Mongols as retainers in war. It has been practiced for a long time; among them about $70 \%$ were Chinese who returned from the barbarian land, and about $30 \%$ were the Mongols who had committed crimes, and came to the Ming side to avoid punishment." This was roughly the real situation during the Jiajing era.

25 Ming jingshi wenbian, 4: 3503. 
allow one barbarian in, and it is never invaded throughout the year. ${ }^{26}$ In March 1595, Minister of War Shi Xing explained more accurately, "Jizhen is close to the royal cemetery, and there is only one wall separating the Ming border from the barbarians. It is critical, and thus the success of Jizhen's defense is just defense and preventing the enemy from breaking in." ${ }^{27}$ Since the Jizhou part of the Great Wall is very close to the Ming imperial tombs, after the mid-Ming, especially after the Gengxu Incident in 1550, this area stuck with the passive defense strategy.

Different from Jizhou, other fortresses along the Great Wall, such as Liaodong, Xuanfu, Datong, Shanxi, Yansui, and Ningxia embraced offense as an effective defense, and Ming policies supported retainers from these areas who conducted daochao and ganma. Aggressive daochao and ganma became quite common during the reign of Jiajing, and Minister of War Shi Xing explained this when he compared the periods before and after the "Longqing Fenggong": "There were internal struggles among Mongols during the Jiajing reign; however, the Ming troops also looked down upon Mongols and often conducted daochao. From the beginning of the border market, people became hesitant to take military action, and the border situation fell to its worst level." ${ }^{28}$ In September of the fourth year of the Jiajing reign, Yang Yan was envious in comparing Jizhou and Xuanda, saying, "The retainers of the Xuanda and Shanxi generals conducted daochao and ganma to sell horses they acquired and get rewards from the court, and everybody is happy doing it. Unfortunately there is no chance of ganma in Jizhen; however, the stipend and logistical allotment are the same as in other counties. The grain stipend is supposed to be two shi each month, but is often delayed

26 Sun Kuang, Sun Yuefeng xiansheng quanji (jiaqing shijiunian yaojiang sunshi keben)5: 45a. The missing character should be "Lu."

27 Ming shenzong shilu, 283 in Ming shilu (Taibei: Taibei zhongyang yanjiuyuan lishi yuyan yanjiusuo jiaoyin, 1962), 57: 5238.

28 Shi Xing, "Shuguan jiwushu," in Wanli Shuchao: 37, Siku Jinhuishu congcan (Beijing: Beijing Chubanshe) 59: 568. 
for months by the local government and nothing is available for soldiers in Jizhen." ${ }^{29}$ Ganma became a reliable source of income for generals and their retainers. Henry Serruys said that Ming troops started sudden forays against Mongols to acquire horses; however the historical documents never recorded this as stealing or raiding, but named it ganma (herding or shepherding horses), and the Ming government never banned these activities. $^{30}$

One group of people who were specially harassed by daochao and ganma was the Duoyanbiebu tribe outside of Longmen. The Duoyanbiebu tribe lived close to the mountains, sandwiched between the Ming and Mongols, and was composed of both Chinese and Mongol residents. They were attacked and raided by the Ming generals. According to Liangzhen sanguan tongzhi (General Gazetteer of Two Military Districts and Three Fortresses),

In March of the twenty-second year of Jiajing, General Xi Yong went out to attack the Mongols in Lijiazhuang. At first there were a couple hundred Mongols residing in Lijiazhuang who belonged to Duoyanbie tribe. They often raided the border area and Ming soldiers watched them carefully. But this camp had no connection to the major Mongol tribe there and sometimes stole horses from there. The big tribe found out and started chasing the Duoyanbiebu. The land is suitable for farming, and gradually Chinese moved and lived there. Each time when they passed by they would send words (to Ming soldiers) that they were on the way to steal horses (from the big Mongol tribe) and wouldn't bother the South (the Ming border). They are sneaky and skilled at archery, but they have never been annexed by the big Mongol tribe. They became the target of the Ming soldiers who want easy credit. Yong led soldiers out and attacked this group, killing more than forty. This move can only harm this group and make them resent the Ming

29 Ming jingshi wenbian, 3: 2025.

30 Henry Serruys, Sino-Mongol Relations during the Ming II, the Tribute System and Diplomatic Missions, 79. 
court. If they feel vulnerable and ask for being annexed by the major Mongol tribe, it will be a huge problem. Regardless of victory or defeat, it is so easy to see what is credit or crime. ${ }^{31}$

The author of the Tongzhi (General Gazetteer) Yin Geng was very critical of those generals who were "scared of the strong enemy but bully the weak one."

In 1544, Ming generals again launched a northern expedition. Su Zhigao, who participated in the expedition, wrote a poem: "We went out to attack Mongol camps at midnight." $32 \mathrm{Su}$ also wrote in his preface to this northern expedition poem, "The Mongols near Longmen often raid. I made a proposal to the governors that 'the best way to attack the Mongol is daochao. We should wait for spring and gather all our troops to attack when the Mongols are scattered. We would do well to attack when the Mongols are not prepared. We should use our best general to lead it, and even a small victory can boost morale, which will lead to bigger victories.' The governors agreed. I went out with Yuan Shu, killed fifty-two Mongols and acquired over a thousand horses, as well as countless cows and sheep. The Ming court also sent a reward after they heard of the victory. Thereafter the Mongols never again attacked Longmen." Su was at the time appointed to the position of Consul of Koubeidao, and the Longmensuolu referred to the Duoyanbiebu tribe. The Ming troops often snuck out and attacked the Duoyanbiebu tribe, killing and raiding these Mongol people and their livestock, and returned without having suffered any losses.

However, sometimes these attacks ended up in disaster. In July of the Jiajing reign, "Generals Lü Yang and Dong Qi attacked the Mongols in Lijiazhuang but were defeated." Yin Geng quoted Weng Wanda: “They

31 Liangzhen sanguan tongzhi (a Jiajing edition held at Asian Division of Library of Congress), 4:28b-29a.

32 Su Zhigao, "Hancunji" in Siku quanshu cunmu songshu (Qilu shushe, 1997), 99: 295. 
vowed to fight for the Ming court. Lü Yang and Dong Qi attacked the Mongols in Lijiazhuang, killed thirty, and returned. It happened to start raining and the Mongols chased after them. They couldn't fight and were defeated. Qi was scared and fled. Yang also barely escaped. More than a hundred Ming cavalrymen were killed. Yang was blamed for his reckless move, and Qi was also punished because he fled instead of rescuing Yang. Both deserved their punishment." 33 This was the same as a typical sudden attack, with the only difference being that Lü Yang was defeated and paid a high price for his mistakes.

The population of the Duoyanbiebu tribe outside of Lijiazhuang was small and weak, and they were no threat at all to the Ming borders. As Yin Geng said, the "Mongols in Lijiazhuang make a living by themselves and weren't annexed by a bigger tribe. When they went out for stealing horses they notified us because they were afraid that Ming soldiers would attack their home base. They actually tried to please us." It was exactly this weak tribe that became the target of raids numerous times just because they were close to the Ming border. It even enraged Yin Geng as he commented, "Lü Yang boasted about attacking Lizhuang. Attacking Lizhuang was the same mistake made by Xi Yong. Xi Yong was weak facing a strong enemy, and bold when facing a weak one." Those Ming generals only dared to attack the weak, and that was the reason why Duoyanbiebu tribe was attacked repeatedly.

Similar to the Xuanfu, the retainers of Shaanxi sanbian were also good at daochao and ganma. Wang Chonggu was appointed Governor of Xuanda in the fourth year of Longqing. When he was governor of Shaanxi Sanbian, Wang organized daochao and ganma every year. Wang later recalled,

I have been a governor of this Sanbian for twelve years. I have been watching the Mongols. When Ji'nang was alive, the tribes were united, his nine sons were strong, and his power reached over to other Mongol tribes.

33 Liangzhen sanguan tongzhi, 4: 41b-42a. 
But Ji'nang died twenty years ago, his tribes divided, and most of his sons died as well. Now that Ji'neng was old and weak, his sons and nephews fought each other. The population has continued to grow and they cannot all live there. Many Mongols came to surrender and each county has their retainer who goes out for daochao and ganma. The Mongols cannot live in peace year around. ${ }^{34}$

Wang continued, "I have been governor of Ningxia for seven years. I often let generals and soldiers of Shaanxi Yanning go out for daochao, and over the years they have killed a thousand Mongols. Altogether the Ming soldiers from the four counties of Shaanxi have killed over three thousand Mongols in five years. The Mongols in this area are much weakened." After the "Longqing Fenggong," Guo Tingwu conducted another round of daochao and ganma. ${ }^{35}$ These well-organized and intensive daochao and ganma efforts drove the Ordos tribe into crisis. When the Tümed tribe started peace talks with the Ming dynasty, the Ordos chief quickly joined the negotiation. Ji'neng's envoy told the Ming official that the Ordos chief has "suffered so much due to daochao and ganma that they cannot live in peace." He went on to note, "When Wang was stationed in the west, his troops killed many Mongols, but now that he is re-stationed in the eastern area, he allows us to pay tribute, and rewards us with silk and clothes; how can we not to follow his command? I am very grateful." 36 When they heard that Altan Khan had started negotiations, they also joined in. After Wang Chonggu left Shaanxi Sanbian, daochao and ganma continued. In November of the fourth year

34 Ming jingshi wenbian, 4: 3369-3370. There is one inevitable question: why did Wang Chonggu kill Mongols when he was at Shanxi, but rush into peace talks when he moved to Xuanda? The Japanese scholar Ono Wako believes that Wang Chonggu was from a Shanxi merchant's family, and Shanxi merchants were close to Zhang Juzheng. This is the primary reason why Wang Chonggu was fully in favor of the Sino-Mongol peace treaty.

35 Ming Muzong shilu, 59 in Ming Shilu, 50: 1439.

36 "Bingbu zoushu" in Zhongguo wenxian zhenben congshu (2007), 286. 
of Longqing, the Governor of Shaanxi Sanbian Wang Zhihao reported, "Generals in Yansui and Ningxia conducted successful daochao, reaching out over five hundred $l i$ and killing one hundred sixty Mongols. The Emperor was pleased and admitted one son of Wang Zhihao to the Ming national university. He also promoted He Dongxu and Lei Long, and rewarded Lü Jing with silver.",37

In the thirty years from 1540 to 1570 , Mongol tribes raided the Ming borderlands, and Ming generals' retainers also conducted daochao and ganma; the result was catastrophic. In dealing with the Daičing Ejei Taiji Incident in 1570, Altan Khan told the Ming envoy Bao Chongde, "The grand master has so many good words and I would like to follow them. Initially I was paying tribute to China, but later Qiu Fu and Zhao Quan came to me and tricked me into claiming to be an emperor. They guided me to attack the Ming fortress, and now it has ended up in chaos. We have been fighting for years and it is no good for either side. Now my grandson came to the South, and made peace between the two states. I am old now; if the Ming dynasty invests in me and allows me to administrate the North, which chief dares to oppose that?"38 Beidi shunyiwang anda dengchen gongbiaowen (Submission memorial from the Northern barbarian King Shunyi Anda) also explained the situation: "The newly invested Beidi king Shunyi Altan kneels down and expresses appreciation. Hail the sacred Ming Emperor, all lands under the heavens belong to the Ming, and the Ming emperor is divine as the son of heaven and lord of all Chinese and barbarians. All barbarians get investiture. I was born in the North and was unaware of how to be a vassal. A long time ago we paid tribute and received investiture from the Ming. However, many tribes were tricked by cunning people and lost their chance to get investiture. We have a growing population and are short of clothes. My nephew Ji'neng is stationed at Huwanghe and the Hexi Daxiao Songshan area; my brother is stationed at Chahan Gennao, which is attached to Duoyan

37 Ming Muzong shilu, 51 in Ming Shilu 50: 288.

38 "Bingbu zoushu," in Zhongguo wenxian zhenben congshu (2007), 55-6. 
Sanwei. It is forbidden to have a market, and we have no clothes. Wool cannot be used in summer, and we need silk. Each time Mongols were tricked into raiding, we got some materials but also lost people and horses. Recently the Ming soldiers often came to raid the Mongols. They killed people and looted horses, and they burnt the grass which made Mongol people and livestock suffer in winter and spring. We deserved our disaster, but we were tricked by Zhao Quan. Now the heavenly emperor, who is wise and has capable generals and soldiers, has extended his grace to the northern area, and my grandson Taiji came to surrender to you. With the emperor's affection, my grandson was not killed, but was taken good care of and was appointed to an official post. I, my brother, my nephew, and my grandson are all grateful for your heavenly benevolence, and are enjoined to become your vassals, and vow not to raid the Ming border. We are happy for the investiture and will be your barbarian vassals forever." The humble nuance expressed in Atlan Khan's words is probably the result of polishing by the Ming translation. However, Altan is right that "Ming raiders came in, killed people and stole horses, burned grasslands, and the Mongol people and horses had a hard time in winter and spring seasons." Altan Khan, along with the Mongol Qarachin Ordos chiefs, sent a letter to the Ming court. Altan Khan's complaint was affirmed when Ming envoys Li Ning and Yang Liang visited the Tümed, Qarachin, and Yongshiyebu chiefs. The biggest problem for the Mongol tribes was the Ming's burning of the grassland, and daochao and ganma.

When Wang Chonggu was governor of Ningxia, he frequently organized daochao and Ganma. As he wrote in his memorial "Queyi Fenggong shiyi shu (Proposal of Fenggong Agreement with the Mongols)", "It has been seven years since I became the governor of Ningxia. The Ming soldiers from Shanxi Yanni went out to do daochao and killed over a thousand Mongols. Both Chinse and barbarians are suffering due to the repeated warfare. Over three thousand Mongols were killed in the past five years in four military districts in Shaanxi. Both sides need to be constantly on high alert to prepare for any sudden attack. Hence I think the fenggong and trade is the only solution that can keep 
everybody safe." 39 Daochao and ganma were conducted by retainers who harassed the Mongol tribes, and in retaliation, the Mongols dispatched patrols to the Ming border, which meant that the Ming troops lived in a constant state of tension. Under this chronic tension, the Ming troops became exhausted, and the Mongols also hoped for peace.

At this point it becomes necessary to describe Sino-Mongol relations in the Liaodong area after 1570. After "Longqing Fenggong," daochao and ganma along Xuanda and Shanxi were prohibited. However, the peace talks did not bring all Mongols to the Fenggong system. daochao and ganma in the Liaodong area were only briefly suspended and quickly resumed after the Fenggong. According to Ming Muzhong shilu (Veritable Record of Emperor Muzong), in April of the fifth year of Longqing, Liaodong governor Zhang Xueyan submitted a memorial stating, "Daochao and ganma can financially support troops and make Mongols focus on their internal issues. The "Fenggong" permitted a market and suspended daochao. Now the Mongols dare to attack us but we cannot fight back; this is a big problem. I humbly request that when Mongols attack, then Ming soldiers can fight back and get rewarded depending on their actions." Zhang's proposal was approved. Retainers of Liaodong generals and the Mongol Chahar chief had a series of confrontations in which this sequence of actions was repeated: raid-daochao --retaliation for daochao. Li Rusong was the son of $\mathrm{Li}$ Chengliang, who tragically died during daochao, and the Ming Emperor Wanli was struck with sadness about this. According to the biography of Li Rusong in the Mingshi (History of the Ming dynasty), "In the twentyfifth year of the Wanli reign, Liaodong commander Dong Yiyuan resigned, and among three recommended candidates, the emperor thought Rusong the best. Rusong appreciated that the emperor thought so highly of him, and hoped to work for him. In April of the second year, the Mongols raided Liaodong. Rusong led a light cavalry force for daochao, but unfortunately fell into a trap and fought to the end. The emperor was

39 Ming jingshi wenbian, 4: 3359. 
heartbroken, and ordered that regalia be bestowed on him and had him buried in his hometown. Rusong was granted the posthumous title Zhonglie (loyal and valiant), and a shrine was built for him." The incident was a result of a direct confrontation between the Chahar chief and $\mathrm{Li}$ Rusong. The Mongol chief invaded Liaodong, and Li Rusong and his retainers didn't fight directly, but sneaked out to conduct daochao, which ended up costing him his life.

With hostility replete with violence and blood, the cycle of provocation and retaliation was repeated. The groups who benefited from this were Ming retainers and Mongol aristocrats, while the ordinary people on both sides suffered tremendously. The Ming budget for border defense was also under pressure. In August 1579, the new governor-general of Xuanda, Zheng Luo, who personally experienced the "Longqing Fenggong," gave detailed information about the situation before 1570: "The lands along Xuanda Shanxi from Jizhou to Yansui measured over two thousand eight hundred and thirty-five $l i$. Much of the fertile land went to waste because the constant Mongol raids made it impossible for anyone to farm there. Hence grain became very expensive because all grain needed to be transported from southern China. Both the soldiers and farmers are exhausted and cannot sustain themselves any longer." With the prolonged South-North hostility, the area along the Great Wall was under constant threat of raids by Mongols, and Chinese farmers could not farm at all. The grain had to be transported from inner China, and the transportation fee could be far more the value of the grain. Altan Khan said, "The war in recent years means that neither side can have a peaceful life." Now it is clear why Wang Chonggu said, "The war between the Chinese and Mongols has caused a sequence of disasters."

\section{Return to the Logic of Nomadic-Sedentary Interaction along the Great Wall}

If daochao and ganma by the Ming generals' retainers were so 
common during the decades before 1570, why did scholars pay no attention to it before? In fact, not only in regard to the sixteenth century, but also overall in research on nomadic-sedentary relations, the initiatives of the agricultural regime have always been overlooked. Why? The most fundamental reason is the unbalanced and biased information in historical documents. Owen Latimore argued, "The explanation, I think, lies in the very nature of wars between peoples of advancing culture and peoples of backward culture, and in the fact that it is the developing, advancing people who leave behind them the written material of history. A people that considers itself civilized is never in its own opinion doing more than 'consolidating its position,' even when it is in fact encroaching on a more backward people. Moreover, the warfare of the backward people, even when it is really in self-defense, normally takes the form of raids, and these are normally chronicled as 'attacks' which justify a further assertion of the authority of the superior people." ${ }^{40}$ The decades before 1570 provide very vivid testimony about the state of Ming-Mongol relations.

The tension between the Ming and Mongols (Northern Yuan) represents the last round of confrontation between agricultural and nomadic regimes in the premodern period. We can ask the same question again, "What were the decisive factors in Sino-Mongol relations?" There were numerous records of Mongols' large-scale raids on the Xuanda border in historical documents from this period. Henry Serruys stated, "Just like in the sixteenth century, Altan Khan repeatedly asked for a tributary relationship but was rejected by the Ming court. Once the tributary relationship fell apart, and there was no chance for trade, a raid would soon follow." In other words, the Mongols needed the Ming dynasty, but once the request for tribute or trade did not get accommodated, the Mongols resorted to military force, and used violence to acquire what they needed. What were the items the Mongols needed from the Ming? Henry Serruys said, "The Mongols needed grains, cotton

40 Owen Lattimore, Inner Asian Frontier of China (New York: American Geographical Society, 1940), 350. 
fabrics, metal pots and agricultural tools (some tribes practiced primitive agriculture, especially the Three Commandaries); the nobles wanted silks and silk garments and other luxuries. This need for Chinese manufactured goods was the most important single factor in Sino-Mongol relations." Surruys continued, "This is no contradiction, but trade and tribute were the only alternative for Mongolia to share in China's superior material wealth. As a matter of fact, at times it seems that both means were adopted at the same time...." ${ }^{\prime 41}$ That is to say, the Mongols made requests to the Ming for what they needed, and if the Ming could not supply what they requested for various reasons, the Mongols turned to military power and used raids to satisfy their needs. This is exactly what Wang Xiaofu concluded: "Relations between a nomadic and agricultural society were in fact the continuity and extension of internal relations in the North, and South-North relations were in fact an extension of internal affairs in the North." It was also because of this commonly accepted opinion that most scholars looked at the nomadic society for reasons for the raids.

Japanese scholar Hagiwara Junpei addressed points similar to Henry Serruys' in his book Mindai Mōko shi kenkyū: "Therefore, the moves of Ji'neng and Altan Khan often took the contradictory forms of raid and trade, war and peace, and the Ming court could not perceive the Mongols' real intentions. However, if we take a closer look, we can find out that in the Gansu area, the Mongol raids were part of their management of western areas and the Ming didn't suffer too much damage. In the Shanxi area, the Mongols' raids occurred because the Ming refused the tributary system, so the Mongols took revenge and plundered what they needed, which paved the way for their next step: to request tributary relations." It is easy to conclude that Altan Khan's raids were intended to press the Ming dynasty, and added leverage for later requests for tributary relations.

41 Henry Serruys, Sino-Mongol relations during the Ming II : The Tribute System and Diplomatic Missions (Bruxelles: Institut belge des hautes études chinoises, 1967), 29-30.

42 Hagiwara Junpei, Mindai Mōko shi kenkȳu (Kyōto: Dōhōsha Shuppan,1980), 254. 
Both scholars agreed that nomadic society needed agricultural society. So far the scholarship on this issue has all focused on the nomadic side. Is it still valid? Wang concurred: "There are sufficient reasons for many scholars to give more emphasis to the nomadic society." 43

The Perilous Frontier: Nomadic Empires and China 221 B.C. to AD 1757 by Thomas Barfield has been one of the most important monographs on inner Asian nomadic-sedentary relations. Since its first publication in English in 1989, it has been translated into many languages. One shortcoming of this book is that Barfield didn't distinguish between the conquest and confrontation periods. Even in reference to the period of confrontation, he still gave emphasis to nomadic society. He started by considering relations between nomadic and agricultural regimes, and proposing that there was an "outer frontier strategy" and an "inner frontier strategy." He applied this hypothesis throughout his book. The so-called outer frontier strategy refers to the nomadic state using violence to raid and acquire booty, to press the Chinese dynasties, switching between war and peace, and requesting more trading posts without occupying Chinese territory. The inner frontier strategy refers to the chief of the nomadic state surrendering and asking for protection and support from the Chinese dynasties in order to defeat their enemy. Whether there was trade or raid is simply due to the changing nature of the nomads' society. This book started with Han-Xiongnu relations and continued through the MingMongol period. Regarding the Ming period, Barfield noted, "The Mongol plateau during the Ming period had multiple unifications, and each transtribal leader had used the outer frontier strategy and blackmailed reward from central China. The Mongols and Oirat used raid to acquire resources. For the price for peace, they requested trade and reward which could allow the nomadic state to be sustained." Backed up by superior military power, the nomadic state persistently pressed central China for resources

43 Wang Xiaofu, "Lun Gudai youmu buzu ruqin nonggeng diqu wenti," in ed. Wang Xiao Fu, Tang Tubo Dashi Zhengzhi guanxishi (Beijing: Beijing daxue chubanshe, 1992), 289-292. 
and maintained their parasitic existence. This is one of the main points of Barfield.

Regarding the connection between trade and raid, Wang Mingke contended, "Trade and raid apparently look very different; however, they have the same function-- instead of producing or hunting, the nomads trade with or raid other people for resources. Getting to a deeper lever, trade, raid, or reward all fell into the broad category of 'exchange.' " Here Wang still focused on the social structure of nomadic society. From an anthropological perspective, raid was a necessary, and non-alternative, choice. Wang divided raids into two patterns: "subsistence raids and strategic raids." The so-called strategic raid is an attack to threaten and frighten a sedentary state in order to achieve an economic or political goal; this is an extension of Barfield's outer frontier strategy. In comparison, Wang gave more emphasis on subsistence raids. The purpose of a subsistence raid is to acquire resources directly; it becomes part of the nomadic economy, and thus it corresponds with seasonal needs. Subsistence raids usually occurred in fall or early winter when the nomads finished their annual pastoral routine, and utilized strong soldiers and horses to secure subsistence. Wang contends that "from the anthropological (human living condition) or historical (history of human living condition) perspective, the Xiongnu conducted raids for subsistence, and this is a necessary choice for their survival." ${ }^{44}$ If the nomads looked tough and roguish to Barfield, the same nomads appeared poor and choice-less to Wang. Comparing to Barfield, Wang broke away from the barbarian paradigm (the equivalent of Xiao Qiging's summary of nomads' inborn greed to plunder), and addressed his sympathy to nomads. However, Wang still focused on the inner structure of nomadic society.

All of the above-mentioned scholars attempted to answer the same question proposed by Wang Xiaofu: "Why did the ancient nomads have to invade agricultural areas?" This question itself has an obvious premise,

44 Wang Mingke, Youmuzhe de jueze: Miandui handiguo de beiya youmu buzu (Guangxi shifan daxue chubanshe, 2009), 135. 
that nomadic society needs agricultural society; once their requests could not be satisfied, nomads would wage war and raid. In other words, it was always the nomads doing the raiding, and the victims were always the farmers. Scholars have also attempted to look into the inner structure of nomadic society for a variety of reasons. However, these approaches also imposed a fixed image on readers--that is, compared to nomadic society, the agricultural society must be rich but always weak and passive. It is always the nomads who started the war, and the southern agricultural regime always got beaten. Regardless of trade or raid, scholars commonly agreed that nomads were superior militarily; therefore, it is always the nomadic society that benefitted. These views underestimated the initiative of agricultural society in interactions between nomads and farmers. In fact, no scholars have attempted to carefully examine the question per se.

The initiative and offense of the agricultural society was confirmed by the daochao and ganma conducted by the Ming retainers in the sixteenth century, and this should not be overlooked. Some Mongol raids against the Ming border were actually to take revenge for those daochao and ganma. Wang Mingke proposed a model of subsistence and strategic raids. However, Wang did not acknowledge another type of raid: the retaliatory raids, the Mongols' revenge against daochao and ganma. This kind of provocation and revenge never got attention from scholars. Qu Jiusi addressed this in his biography of Ji'neng in Wanli Wugong Lu, noting "Lots of generals in border areas have claimed credit for daochao and ganma. Wang Chonggu was afraid that this would provoke the Mongols and prohibited daochao and ganma. Those who violate this will get the death penalty." When Altan Khan was negotiating with the Xuanda governor, Ji'neng of the Ordos plundered Shuangshan Fortress, which looked contradictory. But that was in fact the retaliation in response to the provocation from the Yulin retainers. In this way, the issue that puzzled scholars such as Henry Serruys and Hagiwara Junpei--why did Altan Khan simultaneously conduct tribute and raid--can be seen as having a reasonable explanation. But is it still valid only to give emphasis to the nomadic society? 
The Sino-Mongol border along the Great Wall was a restive area which had its own logic. So far most scholars have left this zone out of their analyses, instead focusing on the inner aspects of nomadic society. Wang Mingke constructed a general reciprocity framework for the inner structure of nomadic society, naming trade as balance reciprocity, and raid as negative reciprocity. ${ }^{45}$ In fact, this theory can also apply to the sixteenth century nomadic-sedentary society along the Great Wall. If the Sino-Mongol's tribute and reward pattern can be considered as general reciprocity, then their horse market and trade can be balanced reciprocity, and the Ming generals' retainers-Mongol tribes also have negative reciprocity. Zhang Tao from the Ming dynasty stated, "Three Mongol tribes in the Xuanda area harassed China, and they came to kill and raid our people, so we also attacked them; they came to raid China, and we also conducted daochao and ganma. Overall the benefit and damage for both sides is relatively even." 46 This is a good example of negative reciprocity. Wang Mingke pointed to the research of anthropologist Louise E. Sweet, who argued, "The camel nomad Bedouin conducts two types of raids; one is reciprocal raids among their tribes, and the other is unilateral raids against others, such as oasis farmers, sheep herders, and agricultural border villagers. Both types are very important to the Bedouin nomadic tribe." We found from the Ming documents that agricultural and nomadic groups also had "reciprocal raids." Unfortunately scholars so far have paid no attention to the aggressive side of agricultural society or to negative reciprocity between the Ming and the Mongols.

\section{Conclusion}

In research on premodern nomadic-agricultural society, most scholars still lack a humanistic attitude toward people who were labeled as

45 Wang Mingke, ibid., 37-8.

46 Xiyuan wenjian lu, juan 59 in Xuxiu Sikuquanshu, 1169: 430. 
"barbarians." Speaking of military mobility in this period, it is unquestioned that the Mongol cavalry force was superior; as Zhang Juzheng described, "The barbarians don't aspire to official ranking and fame, but their troops are fighting with us on the battlefield. They are truly difficult to deal with." ${ }^{47}$ However, the social structure of nomadic society was not predestined for war and raid. Like farmers in agricultural society, nomads were also normal human beings. Due to economic and cultural differences, people from south and north could never think of others in a positive way. Take an example of the practice of slash and burn--the nomads considered grassland as their base of living, while the same land was no more than wasteland from the Ming perspective. The Ming border soldiers burned the grassland each year, and this alone could arouse tensions between the nomadic and agricultural societies. According to Yiyu (Translated Work), "Occasionally thieves came close to our borders during summer and fall, probably just for grass, because they were afraid that the Ming soldiers would burn the grass to ashes. They were not raiders. Our troops defend borders day and night, and get exhausted." These so-called random thieves may have been nomads who just wanted to use the grassland before the Chinese soldiers burned it. This is a normal way to make a living, but unfortunately it was often mistaken for raids and caused the Ming troops to be in a state of chronic anxiety.

Many horrendous incidents along the border area should be blamed on the Mongols. However, as the Northern Song Prime Minister Zhang Xianqi also pointed out, "Not all of the border problems were caused by barbarians; some were the fault of local magistrates in border areas." The Ming Prime Minister Zhang Juzheng also agreed with this and quoted this frequently in discussing border issues. In June 1587, a Mongol Tümed general died in Qinghai while at war with Tibetans and his subjects planned to transport his corpse back to Southern Mongolia. However,

47 Zhang Juzheng, Zhang Taiyue ji (Shanghai: Shanghai guji chubanshe, 1984), 23:276 
when they were passing through the Gansu area, the Ming soldiers intentionally picked a flight which led to a military conflict. Shen Shixing said, "The barbarian chief needs to use the path to transport the coffin, and the Ming government has already given permission. However, one Ming soldier provoked, and many barbarians joined the fight which wound up with numerous casualties. The fault is on us, not with the barbarians. Barbarians are like dogs or sheep; though we cannot transform them with trust and righteousness, we can still contain them using the "Fenggong" agreement. The barbarians cannot openly raid either because they are aware of the "Fenggong" agreement." In short, Shen said, "The recent conflict was because of one soldier's provocation which caused two troops to become involved." It was a time when the Ming and the Mongols still had the Kuangong agreement, but the Ming border soldiers provoked the Mongols, and it led to this incident. In June 1590, the Taozhou Incident occurred in the Gansu area. Wang Jiaping (who succeeded Shen Shixing) identified the cause of this incident: "The Taozhou Incident was the result of reckless moves. The Ming soldiers abused their power and ruined both the authority and benevolence of the Ming dynasty. The cause of rebellion is not always the fault of barbarians."

\section{References}

1. Henry Serruys, Sino-Mongol relations during the Ming II: The Tribute System and Diplomatic Missions. Bruxelles : Institut belge des hautes études chinoises, 1967.

2. __ Sino-Mongol relations during the Ming III : Trade Relations, the Horse Fairs : 1400-1600, Bruxelles : Institut belge des hautes études chinoises, 1975.

3. Owen Lattimore, Inner Asian Frontier of China, New York: American Geographical Society, 1940.

4. Reuven Amitai \& Michal Biran eds. Mongols, Turks, and Others: Eurasian Nomads and the Sedentary World, Leiden \& Boston: Brill, 
2005.

5. Thomas Barfield, Perilous Frontier: Nomadic Empires and China. Cambridge Mass.: B. Blackwell, 1989.

6. Wang Xiaofu, "Lun Gudai youmu buzu ruqin nonggeng diqu wenti" Shixue qingbao (3:1988); also in Wang Xiaofu, Tang Tubo Dashi Zhengzhi guanxishi. Beijing: Beijing daxue chubanshe, 1992.

7. Wang Mingke. Youmuzhe de zejue: Miandui Han diguode beiya уоити buzu. Guilin: Guanxi shida chubanshe, 2008.

8. Xiao Qiqing, "Beiya youmu minsu nanqin gezhong yuanyin jiantao", Shihuo yuekan 1:12; Yuandaishi xintan 303-322. Xinwenfeng chubangongsi, 1983.

9. Zhaqi siqin, Beiya уоитu misu yu zhongyuan nongye minzu zhijiande heping zhanzheng yu maoyi zhi guanxi. Taibei: Zhongzheng shuju, 1973. 
$<$ Abstract $>$

\section{The Great Wall as Perilous Frontier for the Mongols in 16th Century: Reconsidering Nomadic-Sedentary Relations in Premodern Inner Asia}

The existing scholarship in nomadic-sedentary relations has focused on the raids and invasions by nomads against agricultural society, and has attempted to seek internal reasons for this within the nomadic society. Interactive MingMongol history along the Great Wall in the sixteenth century indicates that the agricultural society was also capable of offense. Many raids conducted by nomads were actually revenge for the provocation and raids by the agricultural society, hence they were retaliatory raids. Nomadic-sedentary groups interacted along the Great Wall area; therefore, scholars should turn their attention to this area rather than exclusively search for reasons from internal factors of nomadic society. The razzias upon the Mongols beyond the Great Wall by Ming generals and their retainers have shown that sedentary society were in need of horses, cattle, meat, wool, hides, etc. Ming China's big market for the nomadic goods drove Ming generals and their retainers to do the profitable, risky, but provocative forays against the Mongols in $16^{\text {th }}$ century.

Keywords: Retainers, daochao, ganma, Ming-Mongol Relations, NomadicSedentary Relations, Retaliative Raid 


\section{〈국문초록〉}

\section{6세기 몽골의 위태로운 경계로서의 만리장성: 전근대 내륙아시아에서의 유목민-정착민 관계 재고찰}

테무르 테뮬 (난징대학교 역사학계 조교수)

유목-정착 관계에 관한 기존의 연구는 유목민들의 농경사회에 대한 습격과 침입에 주 목해 왔으며, 그 이유를 유목사회 안에서 찾고자 했다. 16세기 만리장성을 따라 형성 된 명-몽골의 상호조응의 역사는 농경사회 역시 공격의 가능성을 갖고 있었음을 드러 낸다. 유목민에 의한 많은 습격들은 사실 농경사회에 의한 도발과 습격에 대한 보복 의 성격을 갖고 있었다. 유목-정착 그룹은 만리장성을 따라 상호작용하였고, 따라서 학자들은 오로지 유목사회의 내적 요인으로부터 그 이유를 찾고자 하는 것에서 벗어 나 이러한 상호작용에 관심을 돌려야 한다. 만리장성을 넘어선 명의 귀족과 그들 가 복(家僕)들의 침략은 정주사회가 말, 소, 고기, 양모, 가죽 등을 필요로 한다는 것을 보 여준다. 명의 유목민 상품을 파는 시장은 명의 귀족과 그들의 가신들이 16세기 몽 골에 대하여 수익성 있고, 위험이 있지만, 도발적이기도 한 침략을 추진시켰다.

주제어: 가복(家僕), 기병습격, 명-몽골관계, 유목민-정착민 관계, 보복적 습격 